This is also somewhat problematic for diversity and inclusion. Students with the best scores in the university entrance test, who tend to be the most affluent, will have the option to select universities that choose to participate in the free program. The rest, often from less privileged backgrounds, will only find available slots in the less selective, for-profit, or poorly accredited, tuition-charging institutions. Equity could become a serious issue in Chilean higher education, as it is currently in the Brazilian free public system.

\section{FreE FOR ALL}

With financial and access issues entangled in the current version of the law, there is reason to doubt whether the 2020 free-for-all plan will ever become a reality. The funding for this watered-down version of tuition free higher education came from an increase in taxes on Chilean firms. This increase came at a time of general slowing down of the Chilean economy, mostly because of the steep decrease in the price of copper. Currently, the low price of Chilean exports and the anemic growth rate of the nation's economy are not in line with the increase in the educational budget needed to expand free tuition and fund other educational reforms in progress.

Indeed, the 2015 tax hike generated just enough extra revenue in 2016 to pay for the tuition of some 200,000 students. The target of eligible students in 2016 had to be lowered from 60 percent to 50 percent of the poorest students. And the future looks grim. Fiscal adjustments are already in the forecast for 2017 , with education predicted to take the biggest blow. How this will square with the will to open free tuition to vocational higher education is uncertain.

In the longer term, how the government will ultimately manage to fund free higher education for I.2 million students in the public and private sectors remains unclear. This pertains to feasibility. Whether it is also advisable to make higher education free for all is another question.

\section{The Effects of Saudization on the Universities: Localization in Saudi Arabia}

\section{Manail Anis Ahmed}

Manail Anis Ahmed was head of global resource development at Habib University in Karachi, Pakistan. E-mail: manailahmed@gmail.com.
$\mathrm{T}$ The first university in Saudi Arabia was established in I957. Since then, the country has witnessed fast-paced growth in the development of the academy-and the majority of faculty and staff members recruited to help set up and run it have been foreign workers. Now, however, with increasing numbers of young Saudis coming of age and acquiring advanced degrees, there is an urgent labor market need to absorb these citizens into all sectors of the economy, including higher education. This workforce localization has had various consequences on the way universities are staffed and managed, research is produced and supported, and students are educated in Saudi Arabia.

\section{Saudization: Background, Pressures, and Problems}

Saudi Arabia's policy of replacing foreign workers with its own citizens is known as Saudization. Until very recently, the oil rich Saudi kingdom has depended heavily on expatriates to fill jobs. Currently, however, the country is faced with a burgeoning young population that needs to find gainful employment. Unprecedented numbers of young Saudis are also returning to the country after benefiting from the King Abdullah Scholarship Program (KASP) overseas. The Saudi state has been working hard to absorb these qualified citizens into the workforce. As with all economic sectors, this has had an obvious effect on the substantial higher education industry in the country.

The Saudi ministry of labor has in recent years worked quickly to ensure the implementation of new Saudization laws within higher education, and both public and private universities have been quick to comply. Workforce localization at such a rapid pace has been unprecedented in this country-however, academia, for various reasons, has been ill prepared to deal with such a sudden paradigm shift.

\section{How University Business Has Been Affected}

Whereas teaching and research faculty in Saudi universities continue to be a more or less even mix of Saudi and foreign citizens, the administrative positions have overwhelmingly been Saudized. Until recently, the vast majority of university administrators - the departmental administrative assistants, curriculum developers, research center directors, international engagement managers, quality assurance personnel, and so on, have overwhelmingly been foreign citizens. These have been the people tasked with establishing, developing, running, and maintaining, as well as growing academic departments and administrative units within universities. In contrast, it has been easier for the human resource divisions of universities to justify the recruitment and retention of non-Saudi teaching faculty, as Saudi applicants with the required terminal degrees and higher-level teaching and research credentials have been somewhat more difficult to find. Therefore, as opposed to teaching po- 
sitions, university administrative positions have been relatively more quickly Saudized.

This has had an immediate effect on university business. For the most part, inevitably, things have slowed down. This is as much a result of Saudi professional culture as of the lack of previous institutional exposure and relevant professional training received by Saudi administrators. The leadership in Saudi universities must be given credit for having moved quickly and earnestly to meet this challenge. Administrators have been provided with the best available professional development opportunities. Consultants-

\section{Saudi Arabia's policy of replacing for- eign workers with its own citizens is known as Saudization.}

predominantly from Western, English-speaking countries-have been called in to provide training and development for Saudi professional staff. In addition, many Saudi staff members have been sent to prestigious venues abroad for multiple weeks of residential and immersive training. However, on the flip side, this has added to the administrative, bureaucratic, and financial burden of universities.

\section{Problems with Research Production and Support}

According to the country's changing employment laws, key administrative functions such as human resources and finance have been required to become roo percent Saudistaffed. This has caused a significant cultural change within universities, especially with regard to developing systems supporting the production of scholarly research. Financial and logistical arrangements for research now have to be handled by administrative offices staffed by Saudis unfamiliar with global norms. For example, conference attendance allowances and research expenditures are, from time to time, curtailed. These are very often understood by Saudi staff to mean special privileges to be bestowed as favors, not standard allowances for research production to be made available to all eligible scholars.

In "How Saudi Arabia Can Create an Academic Oasis" (Times Higher Education, May 22, 20I4), Philip G. Altbach points out that Saudi academics are awarded immediate tenure in public universities without preconditions regarding academic and/or research productivity. On the other hand, foreign faculty, who still make up 42 percent of the teaching staff in Saudi universities, cannot become eligible for tenured positions, regardless of their performance.
These arrangements do not encourage the ideal outcomes of institutional loyalty or top performance in either group. Quality assurance mechanisms, recently implemented under the guidance of the Saudi NCAAA (National Commission for Academic Accreditation and Assessment), also set a high academic and research standard-but not enough incoming Saudi faculty or staff are yet familiar or comfortable with these expectations.

\section{Inadequate ACademic Preparation of University STUDENTS}

Universities in Saudi Arabia are continuously urged to focus on quality assurance and improvement, with global standards in mind. This is commendable. However, there is a fundamental incompatibility between the academic preparation of incoming Saudi university students and the curricular requirements of university degree programs - most often developed in consultation with non-Saudi advisers. Students are simply not well enough prepared in fundamental areas like writing, quantitative, and analytical skills, to be able to succeed in an undergraduate course. This lack of preparation is simply the result of a disconnect between the very locally oriented public educational system up until high school, and the vastly different, heavily Western-influenced curricula at the university level. To make up for this, all public and some private universities offer foundation programs to incoming students.

Saudi teaching and administrative staff have quickly pointed out that their national universities are simply not ready for the international standards they have been setting for themselves - that quality improvement mechanisms applied to the universities are out of sync with the rest of their national educational system. There is increased pressure on faculty and staff in Saudi universities to facilitate student success, very often at the cost of integrity in teaching, or grading challenging coursework. Dumbing down courses and inflating grades helps institutions graduate more students, but it is not a sustainable practice. Replacing nonSaudi teaching and administrative staff with Saudis has prodded these institutions to begin to find a way to create curricula, teaching and assessment methods, and research expectations that are more in line with their students' and teachers' capabilities.

\section{Possible Solutions}

Employment nationalization of the Saudi academy has provided jobs for many qualified young citizens. Graduates of both national and foreign universities, with bachelor's, master's, and even doctoral degrees in hand, have had a challenging time finding suitable employment in various sectors, because the economy was not adequately prepared 
to replace the existing (overwhelmingly foreign) workforce, and receive a sudden onslaught of newly minted Saudi human resource. In such a situation, academia has been able to absorb substantial numbers of citizens, mainly into administrative positions, but also as part-time lecturers, lab technicians, research assistants, and other support functions.

As an ongoing phenomenon, Saudization within universities is bound to evolve. The Kingdom continues to devote substantial resources toward the development of a world-class higher education system. However, labor market pressures to urgently localize the workforce must be handled thoughtfully. The ministry of education should formulate its own recommendations for Saudization. One could be a more gradual Saudization of administrative positions in higher education, and, accompanying this, thorough training and exposure to international norms of teaching and research for Saudi administrative staff. More locally suited quality assurance mechanisms for faculty members and senior staff with regard to teaching, research, and service-the three essential aspects of the academic experience-should be introduced. Finally, academic preparation at all levels-from college preparatory years to university curricula themselves - must be made more rigorous. This is essential in order for Saudi universities to be able to do their job well: that of educating the country's young citizens to a relevant and employable standard.

\section{Luxembourg's Expanding Higher Education System: Responding to Global Norms}

\section{Gangolf Braband and justin J. W. Powell}

Gangolf Braband is research fellow at the University of Luxembourg. E-mail: gangolf.braband@uni.lu. Justin J.W. Powell is professor at the University of Luxembourg. E-mail: justin.powell@uni.lu.

$\mathrm{T}$ The worldwide expansion of higher education bypassed Luxembourg for some time. In the absence of a national research university, the Grand Duchy lacked capacity for teaching and research. This seemed increasingly anomalous given the rise of the "knowledge economy," especially because Luxembourg, with a population of 543,000, unlike many other small states, is unusually international, ethnically diverse, and prosperous. Luxembourgers seeking to complete a university degree traditionally did so abroad.
Initially, this was not perceived as a disadvantage, but was seen as beneficial in forming a distinguished national elite with European networks. Few incentives existed to expand domestic higher education.

The situation shifted toward the end of the I990s, due to the ongoing expansion of higher education internationally, and Europeanization processes like the Bologna Process and the European Commission's Lisbon Strategy. Indeed, Luxembourg's minister in charge of higher education signed the Bologna declaration in I999-years prior to the founding of the University of Luxembourg (UL), the first and only state-funded national university.

\section{Establishing the First National University in LUXEMBOURG}

Early attempts to establish a university in Luxembourg in the Igth and 2oth centuries failed, thereby initiating the study-abroad tradition, with a practice characterized by an initial period of study of two years in Luxembourg prior to going abroad, and close connections between students abroad and political and societal elites at home, creating a well-defined and closed circle of leaders. Given this environment, the drive for change had to come from the outside. The first research framework program of the European Union (1984) provided such an impulse, but ultimately its effects on higher education were limited. Further international developments triggered only incremental changes. No public pressure counteracted this lack of political willingness to innovate: Higher education was simply not a public issue.

The internationalization of higher education, in the meantime, gained more weight and influenced the country's further development. A few powerful political actors in the responsible ministry instrumentalized the tools provided by the Bologna Process and by the Lisbon Strategy (here especially the demand for increasing investments into research and innovation), to counteract the prevailing opposition and raise awareness. The idea was to create a stronger institutional basis for publically funded research, by establishing a university focusing on graduate degree programs in selected fields aligned to national needs. While keeping the study abroad tradition alive, such a university would expand higher education opportunities, simultaneously contributing to the diversification of the country's economic basis and bolstering Luxembourg's "knowledge economy."

Ultimately, the aim of founding a university was successful, yet in a rather controversial manner, through a top-down process par excellence, characterized by a lack of transparency and few attempts to engage the wider society. The outcome of this approach was not as initially anticipated. Existing postsecondary education institutions were 